\title{
Cell-Based Modulation of Autoimmune Responses in Multiple Sclerosis and Experimental Autoimmmune Encephalomyelitis: Therapeutic Implications
}

\author{
Vasileios Mastorodemos ${ }^{a}$ Marianna loannou ${ }^{b}$ Panayotis Verginis ${ }^{c}$ \\ a Department of Neurology, University Hospital of Crete and ${ }^{b}$ Institute of Molecular Biology and Biotechnology, \\ Foundation for Research and Technology, Heraklion, and ' Biomedical Research Foundation of the Academy of \\ Athens, Athens, Greece
}

\section{Key Words}

Multiple sclerosis · Experimental autoimmmune encephalomyelitis $\cdot$ T regulatory cells $\cdot$ Myeloid-derived suppressor cells $\cdot$ Immunoregulation

\begin{abstract}
Multiple sclerosis (MS) is a prototypic autoimmune inflammatory disorder of the central nervous system (CNS). MS pathogenesis is a complex phenomenon that is influenced by genetic and environmental factors that lead to the dysregulation of immune homeostasis and tolerance. It has been shown that pathogenic T lymphocyte subsets, such as Thelper 1 (Th1) and Th17 cells, play a crucial role in the autoimmune cascade influencing disease initiation, progression and subsequent tissue damage during MS. On the other hand, several mechanisms have been described in both patients and animal models of MS with the potential to modulate myelin-specific autoimmune responses and to facilitate amelioration of disease pathology. To this end, regulatory $T$ cells (Tregs) are considered to be a powerful cell subset not only in the maintenance of homeostasis but also in the reestablishment of tolerance. Along these lines, other cell subsets such as dendritic cells (DCs), myeloid-derived suppressor cells (MDSCs), $\gamma \delta$ T cells and natural killer (NK) cells have been shown to regulate the autoimmune response in the
\end{abstract}

CNS under certain circumstances. This review will attempt to summarize the relevant knowledge of the regulatory mechanisms exerted by immune cells in MS that could hold the promise for the design of novel therapeutic strategies.

ㄷ) 2014 S. Karger AG, Basel

\section{Introduction}

Multiple sclerosis (MS) is a common, complex disorder of the central nervous system (CNS) characterized by immune-mediated demyelination and it is associated with a variety of symptoms that result in functional deficits and handicap. It is the leading cause of neurological disability in young adults and middle-aged people in the developed world [1], affecting $0.05-0.15 \%$ of patients of Caucasian ancestry. MS is considered to be a Tcell-mediated autoimmune disease, with pathogenic $\mathrm{T}$ cells being directed against antigens expressed in the CNS [2-4]. Immune cell infiltration of the brain and spinal cord and the subsequent plaque formation are the key characteristics of MS $[4,5]$. However, a totally differ-

Vasileios Mastorodemos and Marianna loannou made an equal contribution.
Vasileios Mastorodemos, $\mathrm{MD}, \mathrm{PhD}$

Neurology Department, School of Medicine

University of Crete Voutes, Heraklion

GR-71110 Crete PO (Greece)

E-Mail vasmast@yahoo.com 
ent view has recently emerged that challenges the traditional 'outside-in' model and, via reinterpretation of currently available research data, it proposes that MS is a primary degenerative disorder and that the excess inflammation observed is an epiphenomenon due to the host's aberrant immune response ('inside-out' model) [6]. Current knowledge of the mechanisms that are involved in MS pathogenesis and resolution of the disease has been obtained by extensive studies in animal models [4]. Although these findings have significantly advanced the number of therapeutic targets in MS, the currently used treatments [7] still display only modest efficacy in a significant proportion of patients. Thus, a better understanding of the cells subsets and the molecules that regulate the myelin-specific pathogenic response will pave the way for the design of better-tolerated novel therapeutic protocols.

\section{Epidemiology and Genetics of MS}

\section{Epidemiology}

MS is one of the most well-studied diseases, but many aspects of its epidemiology remain obscure or a matter of ongoing debate. Its uneven distribution across the world, still the most apparent epidemiological characteristic [1], gave rise to the traditional view of a positive correlation between MS prevalence (the number of patients with MS alive at a specific date per 100,000 population) and latitude. This was first proposed by Kurtzke [8, 9], who described 3 MS frequency zones: high $(>30$ per 100,000$)$ in the northern parts of Europe and North America, medium (5-30 per 100,000) in southern Europe and the southern USA and low $(<5$ per 100,000$)$ in Asia and South America. This theory was later challenged because reports of increasing prevalence came from many regions $[10,11]$ that had been considered medium frequency zones. However, this issue is still not resolved as recent meta-analyses have come to contradictory conclusions that either support [12] or discard [1, 13] the association of MS prevalence with latitude.

What has become evident in several reports evaluating temporal changes in the incidence (i.e. the number of new cases per 100,000 per year) of MS is a disproportional increase in females over the last 25-50 years [14]. Initially observed in longitudinal studies from Canada [15] and Northern Europe [16], this has recently been confirmed in Mediterranean countries [11]. The increasing femaleto-male ratio was also found in a Canadian study of immigrants (Canadian Collaborative Study) and was steep- est in those migrating from certain regions (northern Europe, USA) and at a younger age ( $<21$ years old) [17]. These findings indicate that environmental factors are operational in MS and may be gender-specific.

\section{Genetics}

In this respect, a search for possible genetic or/and environmental factors that may linked to susceptibility to MS would be the next step. Indeed, systematic geneticepidemiological studies assessing the risks to relatives of MS probands found that first-degree relatives are generally at a 10-25 times greater risk of developing MS than the general population [18]. This risk correlates with degree of kinship, with monozygotic twins having the greater risk $(\times 170)$ followed by offspring from a conjugal pair $(\times 150)[18,19]$. The identification of family aggregation in MS indicated that genetic factors may have a role in disease pathogenesis and prompted research for putative genes. The association of the human leukocyte antigen (HLA) gene cluster in chromosome 6p21.3 with the risk for MS was already known in 1972 [20]. Further gene association and linkage studies identified the HLADR2 (HLA-DRB1*15) as the strongest MS susceptibility locus with heterozygosity conferring an odds ratio (OR) of 2.7 and a homozygosity of 6.7 [21]. In addition, a recent study found a higher female-to-male ratio in affected individuals with $H L A-D R B 1^{*} 15$-positive genotypes compared to those without, thus implicating an epigenetic modification at the major histocompatibility complex (MHC) region, which may explain the excess female-to-male ratio in MS in recent years, as discussed above [22]. However, in other regions several other HLA haplotypes were identified with either a risk-promoting or a protective role, thus revealing a much more complex situation than was originally conceived. Interestingly, in 2007, genome-wide association studies identified 2 new genes, namely those encoding the interleukin (IL)-7 receptor a (IL7R $\alpha$ ) and IL2Ra, as being strongly associated with MS, albeit with relatively modest ORs $(<1.35)$ [23]. Subsequently, the latest screen has identified 52 nonHLA MS risk loci with modest OR in the range 1.1-1.3, almost half of them with over $50 \%$ frequency in patients of European ancestry [24]. As might be expected, the vast majority of these MS-associated loci are located close to or inside genes encoding immune-system-related molecules, strongly supporting the hypothesis that MS is primarily an immune-mediated disease. Despite this great progress in MS genetics, the associated variants so far identified still only explain about $50 \%$ of the inherited risk of MS [25]. 


\section{Immunology of MS}

Autoreactive $\mathrm{T}$ lymphocytes directed against myelin proteins are thought to play a crucial role in the autoimmune pathogenesis of MS. This notion is supported by extensive studies in animal models as well as by evidence obtained from MS patients. First, in humans, disease susceptibility is controlled by genes that are critically involved in $\mathrm{T}$ cell activation such as the $\mathrm{MHC}$ (mentioned above) $[26,27]$. Furthermore, myelin-specific $\mathrm{CD}^{+} \mathrm{T}$ cells have been isolated from the peripheral blood of patients with MS [28-30] and active MS lesions are characterized by infiltrating $\mathrm{T}$ cells with myelin reactivity [3032 ], indicating a prominent role of T cells in CNS pathology during MS.

The potent role of T lymphocytes in MS pathogenesis has been demonstrated via studies in the well-characterized mouse model, termed experimental autoimmune encephalomyelitis (EAE), which closely resembles MS. EAE is induced in susceptible strains of mice upon immunization with CNS antigens in complete Freund's adjuvant including intraperitoneal injection of pertussis toxin [33]. Clinical EAE is characterized by paralysis that starts in the tail muscles and hind legs and then progressing towards the upper limbs. Disease can either spontaneously resolve or follow a chronic phase. Importantly, EAE can be transferred to syngeneic hosts by myelin-specific $\mathrm{T}$ cells isolated from myelin-immunized donors. The encephalitogenic $\mathrm{T}$ cells are $\mathrm{CD} 4^{+}$lymphocytes that, upon myelin recognition, secrete an array of effector cytokines, indicating that myelin-specific $\mathrm{CD} 4^{+} \mathrm{T}$ cells are necessary and sufficient to induce EAE.

The susceptibility as well as the clinical course of EAE can vary depending on the sensitizing antigen and the strain of animal employed. To this end, immunization of $\mathrm{SJL} / \mathrm{J}\left(\mathrm{H}-2^{\mathrm{s}}\right)$ mice with myelin basic protein (MBP), myelin proteolipid protein or their peptides leads to the development of the remitting-relapsing (RR) form of EAE, while immunization of $\mathrm{C} 57 \mathrm{BL} / 6\left(\mathrm{H}-2^{\mathrm{b}}\right)$ mice with myelin oligodendrocyte glycoprotein (MOG) peptide induces the chronic disease phenotype. Similar to in SJL/J mice, immunization of $\mathrm{PL} / \mathrm{J}$ and B10.PL (both $\mathrm{H}-2^{\mathrm{u}}$ ) with MBP peptides results in acute but relapsing EAE. Besides EAE induction in wild-type animals, various $\mathrm{T}$ cell receptor (TCR) transgenic strains with specificity for myelin peptides have been generated and employed in order to study the mechanisms involved in CNS autoimmunity that have been reviewed elsewhere [34]. Collectively, the EAE mouse model has proved an excellent tool for investigating the pathogenetic mechanisms and immunoregulato- ry networks that operate during MS, since, apart from the ethical constraints, factors such as the inaccessibility of CNS tissue have made the investigation of such processes in humans a complicated task.

The autoimmune cascade leading to MS pathogenesis could be divided into several steps (fig. 1). Initially, myelin-specific $\mathrm{T}$ cells should be activated in the peripheral lymphoid compartments upon recognition of myelin antigens presented by professional antigen-presenting cells (APCs). Upon activation, T cells upregulate the expression of cell-surface molecules that facilitate their exit from the lymphoid organs and their migration to the CNS. This step is highlighted by T cell adhesion to vascular walls and extravasation across the blood-brain barrier (BBB). Once in the CNS, activated T cells encounter myelin peptides presented by local APCs (including microglial cells), thereby triggering their effector functions. Specifically, upon recognition of myelin, $\mathrm{T}$ cells proliferate and produce effector molecules including cytokines [tumor necrosis factor (TNF)- $\alpha$, interferon (IFN)- $\gamma$, IL-2 and IL-17] and chemokines. These molecules orchestrate the autoimmune response in the CNS, by attracting and activating inflammatory cells such as macrophages, monocytes, neutrophils, $\mathrm{B}$ cells and $\mathrm{CD} 8^{+} \mathrm{T}$ lymphocytes. Once in the CNS, CD11 b ${ }^{+}$myeloid dendritic cells (DCs) acquire and present myelin peptides leading to the proliferation of infiltrating pathogenic Th17 cells and, in this way, amplify the autoimmune cascade [35]. The net results of this cascade are demyelination, plaque formation and axonal damage $[3,5,36]$.

\section{Pathogenic T Helper Cells in MS and EAE}

There are two major pathogenic effector $\mathrm{CD} 4^{+} \mathrm{T}$ cell subsets in EAE and MS, the T helper type 1 (Th1) and Th17 cells. Th1 cells are the main producers of IFN $-\gamma$ and were thought initially to be the major pathogenic $\mathrm{T}$ cell subset in EAE. To this end, increased levels of IFN- $\gamma$ have been found in the cerebrospinal fluid (CSF) of MS patients and the spinal cords of mice with EAE [37]. In addition, myelin-specific Th1 cells transferred into mice induce severe EAE. However, paradoxical data have demonstrated that IFN- $\gamma^{-/-}$mice that lack Th1 cells develop more severe EAE, indicating that Th1 are not the only pathogenic cells participating in the inflammatory cascade during disease development [38]. Through cytokine profiling, a distinct $\mathrm{CD} 4^{+} \mathrm{T}$ cell subset was described that was characterized by the secretion of IL-17 and was therefore labeled Th17 cells [39]. These are now known to pro- 


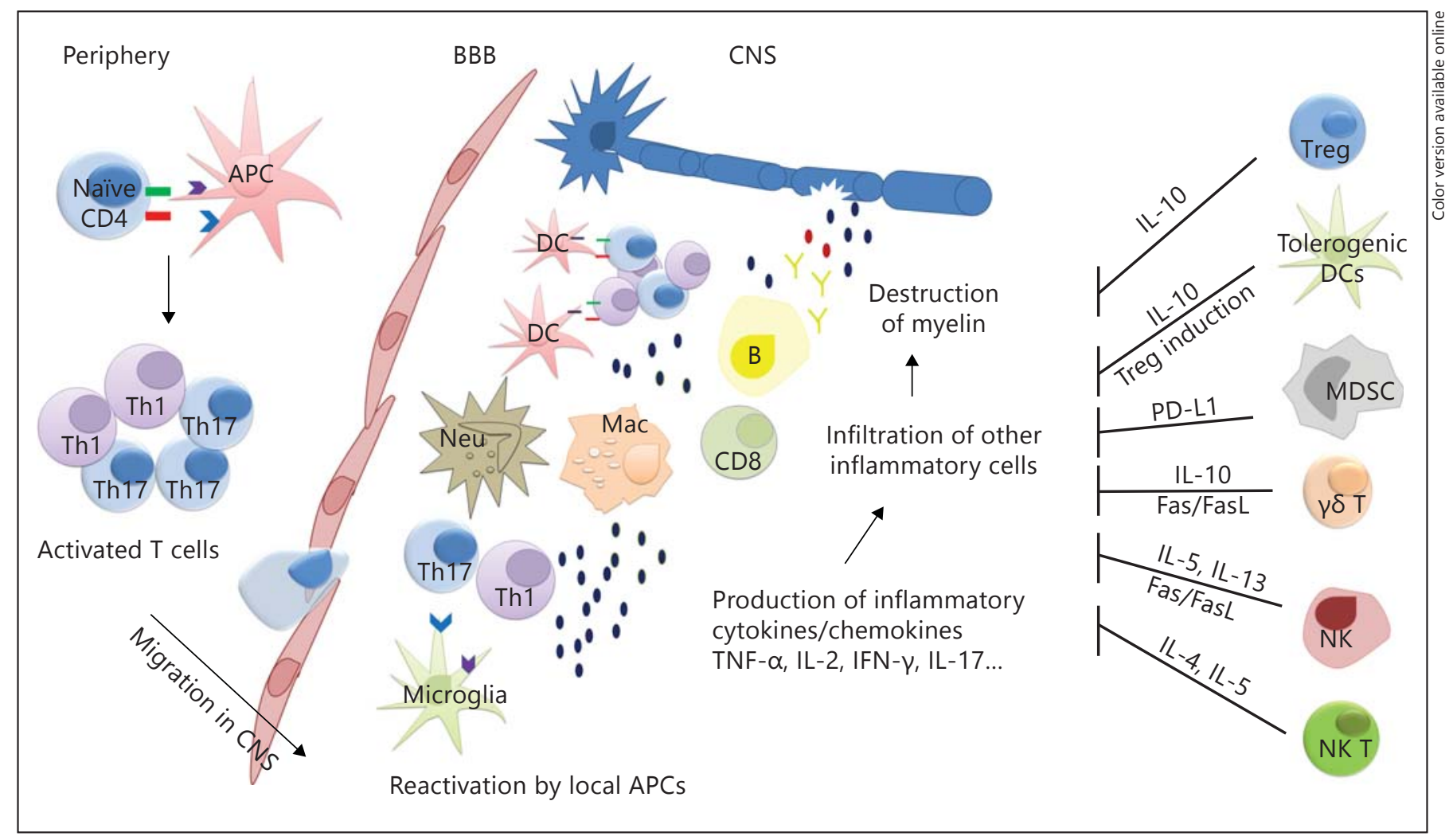

Fig. 1. Myelin-specific T cells that have escaped central tolerance circulate harmlessly in the periphery of healthy individuals and are kept silent by peripheral mechanisms of tolerance. Breakdown of these mechanisms, leads to the activation of clonal expansion followed by extravasation through the BBB to enter the CNS. Subsequently, infiltrating $\mathrm{T}$ lymphocytes encounter myelin antigens presented by local APCs and exert their pathogenic function via the secretion of inflammatory cytokines/chemokines, thereby am-

duce IL-17, IL-21 and TNF- $\alpha$ and have been shown to be pathogenic in EAE [40]. In MS, the analysis of MS tissue has demonstrated the presence of Th17 cells in lesions as well as in the blood of patients with MS [41]. Overall, Th1 and Th17 cells play a crucial role in the pathogenesis of $\mathrm{EAE}$ and have been linked to the demyelination process during MS.

\section{B Cells in MS and EAE}

It has been proposed that B cells mainly exert a pathogenic role in CNS autoimmunity through (1) the secretion of autoantibodies that react against myelin that contribute to demyelineation and axonal damage and (2) the presentation of myelin antigens to $\mathrm{T}$ lymphocytes, thus promoting autoreactivity. The presence of oligoclonal plifying the inflammatory cascade. This involves the recruitment of DCs, macrophages, neutrophils, B cells and CD4/CD8 T cells that contribute significantly to the destruction of myelin. However, these responses have been shown to be counterbalanced by modulatory mechanisms involving cell subsets such as Tregs, DCs, MDSCs, $\gamma \delta \mathrm{T}$ cells, NK and NK T cells with the ultimate goal being the suppression of the autoimmune response and disease remission.

bands in the CSF of $>95 \%$ of MS patients is the most consistent immunologic finding that argues for an abnormal $B$ cell activation within the CNS [42]. In addition, the presence of ectopic meningeal B cell follicles in a substantial proportion of secondary progressive MS patients was associated with a more severe disease phenotype (disease onset at an earlier age and disability) and extensive cortical demyelination [43]. More recently, histopathological analysis of tissues from MS patients demonstrated the deposition of antibodies and complement on the myelin sheath of lesions, supporting the notion that B cells play an important role in disease pathogenesis [44]. As such, in MS patients in several past and ongoing phase II and III trials, treatment with rituximab or ocrelizumab depleted $\mathrm{B}$ cells positive for the $\mathrm{CD} 20$ antigen reduced gadolinium-enhancing lesions and tended to reduce the relapse rate. However, anti-CD20 therapy does not target 
plasma cells and does not influence the presence of oligoclonal bands, which indicates that autoantibody production is not the main mechanism mediating the pathogenic role of B cells in MS [42].

The potential role of $\mathrm{B}$ cells and antibodies in EAE development has been demonstrated in myelin-specific TCR transgenic mice crossed with mice expressing the heavy chain of a myelin-specific antibody. It was found that double transgenic mice developed an aggressive autoimmune disease affecting the optic nerves and spinal cord [45]. Although these data indicate that B cells play a pathogenic role in EAE, several reports have proposed that this subset plays an immunoregulatory role in disease pathogenesis; this will be discussed in the following section of this review.

\section{Regulatory Subsets in MS and EAE}

It is well accepted that, in healthy individuals, central tolerance mechanisms are incomplete, resulting in the production of self-reactive $\mathrm{T}$ cells in the periphery. Once in the periphery, these cells are kept in check by additional mechanisms of tolerance, either recessive (anergy, deletion and ignorance) or dominant (regulatory T cells) [46]. Autoimmune diseases are thought to emerge upon disruption of any of these mechanisms that leads to the activation of these self-reactive $\mathrm{T}$ cells. Therefore, it is of great importance to better understand how individual cell subsets and molecules participate in the maintenance of immune homeostasis and tolerance as well as to investigate the mechanisms that might be involved in the reestablishment of tolerance when disrupted. Here, we review the literature on the different cell subsets that have been shown to modulate the autoimmune responses in patients with MS and in the EAE mouse model.

\section{Regulatory T Cells}

Over the last 2 decades, strong evidence has emerged for a dominant role of regulatory $\mathrm{T}$ lymphocytes in the regulation of self-tolerance and the maintenance of immune homeostasis in both humans and mice [47]. Initial experiments demonstrated that the depletion of $\mathrm{CD} 4{ }^{+} \mathrm{CD} 25^{+} \mathrm{T}$ cells from normal animals leads to the spontaneous development of various autoimmune diseases such as gastritis, thyroiditis and type 1 diabetes whereas the reconstitution of normal CD $4{ }^{+} \mathrm{CD} 25^{+} \mathrm{T}$ cells prevents these disorders [48, 49]. Following the potent regulatory function of the $\mathrm{CD} 4^{+} \mathrm{CD} 25^{+} \mathrm{T}$ cell subset, these cells were termed regulatory $\mathrm{T}$ cells (Tregs). Subse-

Cell-Based Modulation in MS and EAE quent extensive research established that Tregs are divided into two major subsets: naturally-occurring Tregs (nTregs) and inducible Tregs (iTregs) [50]. nTregs are thymic-derived cells that constitute $5-10 \%$ of the total of peripheral $\mathrm{CD} 4^{+} \mathrm{T}$ cells, whereas iTregs are generated in the periphery upon exposure of naïve $\mathrm{T}$ cells to several tolerogenic stimulus. A breakthrough in the field came with the identification of the transcription factor forkhead box P3 (FoxP3) as a specific marker for Tregs [5153]. Foxp 3 expression was also proven to be crucial for Treg development and function. Most importantly, the absence of Tregs due to FoxP3 gene mutations led to the development of severe autoimmune disorders, known as the scurfy phenotype in mice and the IPEX syndrome (immune dysregulation, polyendocrinopathy, enteropathy and X-linked syndrome) in humans [54].

\section{Tregs in MS}

Autoreactive $\mathrm{T}$ cells specific for myelin antigens are present in healthy individuals, suggesting that they are kept silent by regulatory mechanisms that turn out to be defective with MS. Indeed, several reports have demonstrated an impairment of Treg function in MS. To this end, $\mathrm{CD} 4^{+} \mathrm{CD} 25^{\text {high }}$ Treg cells isolated from the peripheral blood of MS patients were found to have a defective suppressive function in vitro [55-57], even though their frequencies were not altered $[58,59]$. Interestingly, Treg suppressive activity was restored upon treatment with IFN- $\beta[60,61]$, glatiramer acetate (GA) [62] or steroids [63] and remission was achieved. The defective function of Tregs was also correlated with a decreased expression of Foxp3 at both the mRNA and the protein level [64]. Concerning the newer monoclonal antibodies, a recent study showed that natalizumab treatment blocked the transmigration of Foxp3+ Tregs, similar to nonregulatory $\mathrm{T}$ cells, and did not restore the impaired function of Tregs in MS patients. This occurred even though the frequency of peripheral blood Tregs was unaffected by natalizumab treatment and the suppressive capacity of $\mathrm{D} 4{ }^{+} \mathrm{CD} 25^{\text {high }} \mathrm{CD} 127^{\text {low }}$ Foxp3 + Tregs under in vitro conditions was not altered [65]. Even more recently, alemtuzumab, an anti-CD52 humanized monoclonal antibody that depletes potently circulating B and $\mathrm{T}$ lymphocytes in the repopulation process that follows alemtuzumab administration, a population enriched with $\mathrm{T}$ cells with a regulatory phenotype (i.e. anergy to stimulation with allogeneic DCs and the ability to suppress the allogeneic response of autologous T cells) is recognized. In addition, alemutuzumab's ability to suppress T cells seems to rely on the presence of CD25 $5^{\text {hi }} \mathrm{T}$ cells [66]. 
Whether Tregs play a role in the suppression of autoreactive $\mathrm{T}$ cell responses in the target organ is less clear. A greater occurrence of nTregs has been found in the CSF of MS patients, but the suppressive ability of these cells is also impaired. However, a more recent study showed that an increased proportion of Tregs in the CSF expressed the $\mathrm{CD} 45 \mathrm{RO}^{\text {hi }} \mathrm{CD} 95^{\text {hi }}$ phenotype that is sensitive to apoptosis, hypothesizing that Tregs might die via apoptosis within the MS lesion.

Additional evidence for a potential role of Tregs in the pathogenesis of MS was obtained through genome-wide association studies, which identified single nucleotide polymorphisms associated with disease risk. Specifically, CD25, CD127 and CD58, all closely related to Treg homeostasis and function, have been identified as MS susceptibility genes.

\section{Tregs in EAE}

More definitive evidence for the potential role of Tregs in MS pathogenesis has been obtained in the EAE mouse model. Initially, it was shown that a population of $\mathrm{CD} 4^{+}$ $\mathrm{T}$ cells that did not express the transgenic receptor was able to prevent the development of spontaneous EAE in immunodeficient $\left(\mathrm{RAG}^{-/-}\right)$MBP TCR transgenic mice $[67,68]$. Furthermore, the adoptivetransfer ofCD $4^{+} \mathrm{CD} 25^{+}$ $\mathrm{T}$ cells reduced the onset and disease severity in MOGinduced EAE [69]. The protective effects of $\mathrm{CD} 4^{+} \mathrm{CD} 25^{+}$ Treg cells appear to be mediated by IL- 10 since Treg cells for IL-10 $10^{-1-}$ mice failed to ameliorate disease [70]. Furthermore, Treg depletion via the administration of antiCD25 resulted in an increased severity of EAE that was accompanied by increased mortality [71] and rendered the resistant B10 mouse strain susceptible to EAE [72].

Treg cells have also been shown to play a prominent role in the remission phase of EAE. It has been demonstrated that Tregs accumulate in the CNS at the peak of the disease, and their depletion inhibits recovery. An important question that arose from these findings was whether the increased Treg frequency was due to the expansion of pre-existing nTregs or the conversion of nonTreg cells. Korn et al. [73], using transfer of Foxp3-GFP $\mathrm{T}$ cells, were able to demonstrate that Tregs in the CNS were expanded from pre-existing Tregs, rather than converted. Interestingly, the same study showed that although Tregs were increased in the CNS at the peak of the disease, they were unable to suppress myelin-specific $\mathrm{T}$ cell responses in vitro, possibly due to the increased levels of inflammatory mediators in the CNS [73]. On the other hand, neurons have been shown to convert effector T cells into Tregs in a TGF- $\beta$-dependent manner [74]. Collec- tively, these studies demonstrate that Treg cells have the potential to suppress ongoing myelin-specific autoimmune responses.

\section{Dendritic Cells/Monocytes}

DCs are characterized as professional APCs with a unique ability to initiate immune responses by priming naïve T lymphocytes. Two major subsets of DCs have been described, conventional DCs (cDCs) of myeloid origin and plasmacytoid DCs (pDCs) of lymphoid origin. Despite their prominent immunogenic role, under certain circumstances, DC subsets have been demonstrated in both mice and humans to possess a regulatory role, and are thus characterized as tolerogenic DCs [75-77].

\section{Dendritic Cells}

There are several studies that have addressed the regulatory role of DCs in MS and EAE. To this end, it was demonstrated that TNF- $\alpha$-treated DCs express a semimature $\mathrm{DC}$ ( $\mathrm{smDC}$ ) phenotype; intravenous injection of MOG-pulsed smDCs significantly ameliorated EAE [78]. In another study, intraperitoneal injection of embryonic stem cell-derived DCs transfected with programmed-death ligand 1 (PD-L1) in mice with EAE prevented disease development [79]. Although the precise mechanism involved in the amelioration of EAE by tolerogenic DCs remains unclear, other lines of evidence suggest that tolerogenic DCs might promote the induction and/or expansion of Treg cells. This feature was closely attributed to pDCs where it was demonstrated that autoantigen-presentation by $\mathrm{pDCs}$ inhibited EAE via the induction of Treg cells, and the selective inhibition of MHC class II expression by pDCs exacerbated pathology [80]. Furthermore, the antibody-mediated depletion of pDCs during the acute phase of EAE significantly exacerbated disease, indicating a regulatory role for pDCs during the progression of the autoimmune response [81]. In contrast, the depletion of pDCs during the priming of EAE significantly reduced disease onset and severity [82], suggesting that it depends on the disease stage and the respective microenvironment as to whether DCs possess a stimulatory or a tolerogenic role. IFN- $\beta$ was thought to exert its action by downregulating the expression of costimulatory molecules and thus decreasing the production of IL-12 by DCs, which is required for differentiation to Th1 [83]. More recently, it was suggested that the inhibition of the processing of Toll-like receptor 9 (TLR9) underlies the beneficial effect of IFN- $\beta$ treatment in RRMS/CIS patients compared to untreated patients, since activated pDCs separated from 
IFN- $\beta$-treated patients had significantly reduced levels of the processed TLR9 protein, which resulted in a decreased production of both IFN- $\alpha$ and the proinflammatory cytokines IL- 6 and TNF- $\alpha$ [84]. Furthermore, IFN- $\beta$ efficacy in RRMS has been linked with its ability to suppress IL-23 and IL-1 $\beta$ production and increase IL-10 production in human DC treatment [85]. Natalizumab also seems to decrease the expression of MHC class II molecules and the number of CD209 DCs, as shown in a recent report [86].

\section{Monocytes}

Monocytes are circulating blood cells that constitute almost $5-10 \%$ of the total leukocytes in mice and humans. They are highly heterogeneous cells, characterized mainly by the expression of the CD14 and CD16 antigens in humans and CD11b, F4/80 and CD115 in mice. In the field of CNS autoimmunity, GA, currently used as a therapeutic modality in MS patients, has been shown to directly affect the function of monocytes, rendering them regulatory. Initial studies demonstrated that GA treatment in humans increased the IL-10 production by DCs and inhibited IL-12 secretion [87, 88]. Recently, Weber et al. [89] reported that GA promoted the development of type II monocytes that have the capacity to instruct the differentiation of Th2 cells and Tregs cells. Indeed, adoptive transfer of GA-treated type II monocytes induced Tregs in vivo and conferred protection from EAE. In addition, it was recently suggested that a lack of response to IFN- $\beta$ treatment may be related to perturbations of the type I IFN signaling pathway in monocytes. This was based on the observed selective increase in phosphorylated STAT1 levels and IFN receptor 1 expression in the monocytes of IFN- $\beta$ nonresponders in MS patients at baseline, which resulted from an increased monocyte type I IFN secretion upon the innate immune stimuli via TLR4 [90]. With regard to the most recent MS treatments, natalizumab was associated with decreased numbers of CD14+ monocytes, and possibly their migratory potential, since their expression levels of $\alpha 4 \beta 1$ were decreased, whereas fingolimod treatment resulted in a higher fraction of monocytes in the peripheral blood and CSF [91]. Notably, macrophages and monocytes express only low levels of CD52 and, as such, undergo minimal and transient depletion after alemtuzumab treatment, which does not impair their functionality [92]. At present, it is not clear whether the new oral compounds such as laquinimod, teriflunomide or dimethylfumarate affect the components of the innate immune system.

Cell-Based Modulation in MS and EAE
Among the different subsets of monocytic cells, classically activated M1 macrophages and alternatively activated M2 macrophages have received considerable attention. M1 macrophages protect the host during viral or bacterial infections and also participate in antitumor responses, while M2 macrophages have anti-inflammatory properties and have been shown to regulate immune responses [93]. In EAE, CNS-infiltrating macrophages polarize T cells towards pathogenic Th1 cells [94] and it has been proposed that M1-like macrophages contribute to axonal loss [95]. In contrast, other studies have demonstrated the protective role of macrophages in CNS demyelination via the induction of apoptosis in infiltrating $\mathrm{T}$ effector cells as well as via the secretion of anti-inflammatory cytokines such as IL-10 and TGF- $\beta$ [96].

\section{Myeloid-Derived Suppressor Cells}

Myeloid-derived suppressor cells (MDSCs) consist of a heterogenous population of the myeloid precursors of macrophages, DCs and granulocytes, that, functionally, have been shown to potently suppress the ongoing immune response [97-104]. They are characterized by the coexpression of Gr-1 and CD11b and they can be divided into cells with monocytic $\left(\mathrm{CD} 11 \mathrm{~b}^{+} \mathrm{Ly} 6 \mathrm{C}^{+} \mathrm{Ly} 6 \mathrm{G}^{-}\right)$or granulocytic $\left(\mathrm{CD}_{11 b^{+} \text {Ly6 }} \mathrm{C}^{\text {low }} \mathrm{Ly}_{6 \mathrm{G}^{+}}\right)$morphology $[97,105-$ 108]. The role of MDSCs in the field of autoimmunity and particularly in MS is just emerging. To this end, we were the first to demonstrate, in the blood of patients with active MS, a significant enrichment of $\mathrm{CD} 15^{+} \mathrm{CD} 33^{+} \mathrm{HLA}$ $\mathrm{DR}^{\text {low }} \mathrm{CD} 14^{-}$MDSCs that potently suppress autologous $\mathrm{T}$ cell proliferation in vitro [108]. Additional evidence was obtained in the EAE mouse model that the adoptive transfer of granulocytic MDSCs reduces the severity and delays the onset of disease. Moreover, G-MDSCs inhibited the priming of myelin-specific Th1 and Th17 priming via the coinhibitory molecule PD-L1. In line with our mouse-model data, Dardalhon et al. [109] reported that $\mathrm{CD}_{11} \mathrm{~b}^{+} \mathrm{Ly}_{6} \mathrm{G}^{+}$MDSCs regulate Th1 responses and EAE development. Conflicting data have been obtained regarding the role of the monocytic MDSC subset. Thus, in 1 study, CD $11 b^{+}{\text {Ly } 6 C^{+}}^{+}$MDSCs suppressed myelin-specific $\mathrm{T}$ cell responses in vitro [110], whereas 2 other reports demonstrated a pathogenic role of the same cell subset during the effector phase of EAE $[111,112]$.

Although the investigation of the role of MDSCs in suppressing autoimmune responses is still in its infancy, the increased immunosuppressive properties of these cells make them a potential target for the design of therapeutic protocols of diseases of the CNS and other autoimmune diseases.

Neuroimmunomodulation 2015;22:181-195 DOI: $10.1159 / 000362370$ 
$\gamma \delta T$ Cells

$\gamma \delta$ T cells represent an infrequent T cell subset. They express a distinct TCR composed of two glycoprotein chains, termed the $\gamma$ and $\delta$ chains. It has been demonstrated that $\gamma \delta$ T cells recognize antigen in the context of MHC class IB molecules and have a prominent role in the recognition of lipid antigens.

Although $\gamma \delta$ T cells have been shown to contribute to MS pathogenesis via a cytotoxic function, other reports indicate that they could also exert an immunoregulatory role and thus mediate amelioration of the disease. A potential immunoregulatory role of $\gamma \delta$ T cells in MS has been proposed by a study in which MBP-specific T cells were used to vaccinate MS patients in an attempt to induce immune tolerance. It was demonstrated that $\gamma \delta \mathrm{T}$ cells expanded in response to the vaccine and produced high levels of IL-2, TNF- $\alpha$ and IL-10 [113], proposing a possible regulatory role, in contrast to encephalitogenic $\mathrm{T}$ cells. Furthermore, another study showed that treatment of MS patients with IFN- $\beta 1 \alpha$ was correlated with decreased levels of IL-12 and an increase in IL-10 secretion by $\gamma \delta$ T cells, suggesting that this cell subset plays a regulatory role [114].

The immunomodulatory potential of $\gamma \delta$ T cells is further supported by studies in EAE, where the depletion of these cells in spinal cord homogenate-immunized B10.PL mice aggravated disease and decreased antigen-specific $\mathrm{T}$ cell responses [115]. In a similar vein, $\gamma \delta \mathrm{T}$ cells were shown to exert immunoregulatory properties during EAE by inducing the apoptosis of encephalitogenic $\alpha \beta$ T cells [116] in a Fas/FasL-dependent manner.

Overall, the precise role played by $\gamma \delta$ T cells in the regulation of EAE and MS has not been fully elucidated because contradictory results have been reported in studies that used different mouse strains and different strategies to address this task. The conditions under which $\gamma \delta \mathrm{T}$ cells could exert immunomodulatory properties in MS need further investigation.

\section{$B$ Cells}

Several lines of evidence have indicated an immunoregulatory role for $\mathrm{B}$ cells in the development of EAE. To this end, a subset of $B$ cells characterized as $\mathrm{CD} 1 \delta^{\mathrm{hi}} \mathrm{CD} 5^{+}$has been shown to secrete elevated levels of IL-10 during EAE development, and adoptive transfer experiments have demonstrated its participation in the amelioration of disease [117]. In addition, B cells have been shown to chemoattract Treg cells to the CNS at the peak of the disease and to influence the recovery phase [118].

\section{NK and NK T Cells}

Natural killer (NK) cells are a heterogeneous population of lymphocytes that lack antigen-specific receptors, and were originally described as playing a critical role in innate immune responses.

NK T cells are of lymphocytic origin, sharing the properties of T and NK cells. NK T cells are distinct from conventional $\mathrm{T}$ lymphocytes, since they express a heavily biased TCR repertoire that usually recognizes lipid antigens such as a-galactosylceramide [119], in the context of the monomorphic MHC class I-like molecule CD1 $\delta$ [120122]. Upon activation, both populations secrete various cytokines, chemokines or cytotoxic enzymes, thus contributing to innate and adaptive immune responses. There are several studies suggesting that NK and NK T cells could downregulate immune responses [123-127]. In addition, accumulative data also support the active involvement of these cells in the immunoregulation of MS.

\section{NK Cells}

Initially, reduced numbers of NK cells and their impaired functional activity were reported in MS patients, indicating a possible regulatory role of this cell subset in MS pathogenesis [128-130]. Subsequently, NK cells isolated from MS patients in remission were shown to express high levels of Fas (CD95) and to secrete Th2 cytokines such as IL-5 and IL-13 [131-133]. NK cells with this phenotype were termed NK2 cells and were proposed to downregulate IFN- $\gamma$ secretion by $\mathrm{T}$ cells from PBMCs, upon stimulation with MBP [131].

The regulatory role of NK cells is further supported in rodent models of MS. Specifically, in vivo depletion of NK cells by anti-NK-cell antibody administration exacerbated the clinical features of disease and induced fatal $\mathrm{EAE}$, suggesting a protective role of NK cells in EAE development [134]. In line with this, the depletion of NK cells in MOG-induced EAE resulted in a more severe form of disease and augmentation of Th1 responses in response to myelin antigen [135]. Moreover, several studies have correlated NK activity with the suppression of proinflammatory cytokine secretion (such as IFN- $\gamma$ and TNF- $\alpha$ ) by encephalitogenic T cells [136-139]. Furthermore, bone marrow-derived NK cells exhibit potent inhibitory effects on autoreactive $\mathrm{T}$ cell proliferation to both Con A and MBP in dark agouti rats [140]. Although it has been postulated that NK cells might directly affect the interactions between DCs and T cells [141, 142], the precise molecular mechanisms via which they downregulate autoimmune encephalitogenic responses have still to be determined. 
It is noteworthy that daclizumab, a humanized monoclonal antibody against IL-2 receptor $\alpha$ chain (IL2RA or CD25) that showed benefits in clinical and imaging parameters in patients with RRMS, is thought to exert its biological effect by the expansion of immunoregulatory NK cells (NK CD56 bright) [120]. Of the other recently introduced therapies for MS, natalizumab treatment exerts no significant effects on NK cells, whereas in fingolimodtreated patients, elevated NK cells have been observed both in the periphery and in the CNS [91]. NK cells from alemtuzumab-treated huCD52 mice also retain their ability to lyse target cells in vitro [92]. It is currently not known if laquinimod, teriflunomide or dimethylfumarate act on NK cells.

\section{NK T Cells}

Similar to observations in NK cells, the frequency of the $\mathrm{Va} 24^{+} \mathrm{NK} \mathrm{T}$ cell subset was significantly reduced in the periphery of MS patients compared to healthy controls [143]. In addition, $\mathrm{CD} 4^{+} \mathrm{NK} \mathrm{T}$ cells isolated from MS patients in remission were characterized by increased levels of IL- 4 secretion, but the production of IFN- $\gamma$ was diminished [144]. In a recent longitudinal study, IFN- $\beta$ treatment of MS patients significantly increased the percentage of NK T cells in the PBMCs that were characterized by elevated production of IFN- $\gamma$, IL- 4 and IL- 5 upon glycosphingolipid a-GC stimulation [145].

The results obtained from EAE studies have provided a better understanding of the role of NK T cells in the regulation of disease. To this end, a series of elegant reports has demonstrated that the activation of NK T cells by the administration of the glycosphingolipid a-galactosylceramide can result in the amelioration and even full prevention of EAE [146-148]. These results raise important implications regarding the therapeutic potency of glycosphingolipids because these ligands can also activate human NK T cells, thus providing an approach that could be promising for the treatment of MS. Finally, NK T cells have been shown to actively participate in the recovery phase of EAE, so they do possess a regulatory role [149].

\section{Astrocytes in MS}

Until recently, astrocytes, apart from their role in establishing the BBB, were considered 'bystanders' in acute MS plaques or as responsible merely for the formation of a gliotic scar in chronic MS lesions [150, 151]. However, in the last 10 years, the discovery that neuromyelitis op- tica (NMO), a demyelinating condition initially considered to be an atypical, aggressive MS variant, is caused by antibodies against aquaporin-4 [(AQP4) the most abundant water channel protein in the CNS, mainly expressed on astrocytic foot processes], created an upsurge of interest and called for a reappraisal of the role of astrocytes in MS. As such, in pathologic specimens of active MS lesions, the findings of loss of perivascular astrocyte endfeet and astrocyte hypertrophy at the margin of the acute lesion were unambiguous. Notably, astrocyte damage persisted even after acute inflammation and macrophage activity had subsided [151]. Evidence is accumulating (extensively reviewed by Brosnan and Raine [151]) that astrocytes may contribute to lesion development in MS by expressing cytokines and chemokines that attract leukocytes to sites of injury in the CNS and by acting as tissue-damage mediators by producing factors toxic for oligodendrocytes and neurons. In addition, they are mechanistically involved in disruption of the BBB and may also have a role in upregulating adhesion molecules and matrix metalloproteases, thus facilitating the entry of activated T lymphocytes into the CNS parenchyma. Astrocytes possibly also contribute to lesion repair not only through scar formation but also through limiting lesion development [151]. Furthermore, it has been suggested that axonal degeneration in MS may be associated with mitochondrial energy failure. In this respect, white matter astrocyte dysfunction may play a role. It is postulated that white-matter astrocytes in MS show a reduced metabolism of adenosine triphosphate-generating phosphocreatine, which may impair the astrocytic sodium potassium pump and lead to a reduced sodium-dependent glutamate uptake, thus leading to extracellular glutamate accumulation. In addition, a deficiency in astrocytic $\beta 2$ adrenergic receptors may be responsible for a reduced glycogenolysis, resulting in a decreased formation of lactate and glutamine, which are energy sources for axons, and for increased levels of nitric oxide. All these mechanisms may impair axonal mitochondrial metabolism, maybe via $\mathrm{Ca}^{+2}$-mediated excitotoxicity, leading to axonal degeneration [152]. As mentioned above, NMO is now envisaged as primary astrocytopathy with secondary demyelination, since pathological studies have demonstrated the extensive loss of immunoreactivities for the astrocytic proteins, AQP4 and glial fibrillary acidic protein in active NMO lesions in contrast to increased AQP4 in active MS lesions, thus supporting the notion that astrocytes are selectively targeted in NMO. In addition, recent experimental studies have confirmed that the AQP4 antibody, the hallmark of NMO diagnosis, is indeed 
pathogenic, since it results in selective astrocyte destruction and dysfunction in vitro, ex vivo and in vivo [153]. In mice lacking sphingosine-1 phosphate (S1P1) receptor on glial fibrillary acidic protein-expressing astrocytes but not on neurons, the efficacy of fingolimod, a known S1P1 receptor modulator, is lost, and attenuation of EAE severity has been observed, despite a normal response to fingolimod with respect to lymphocyte trafficking [154], thus pointing to astrocytes as possible targets for therapy. Finally, a new oral molecule, laquinimod, which is being tested as an immunomodulatory therapy for RRMS, has been found to markedly reduce NF- $\kappa \mathrm{B}$ (a transcription factor essential for the rapid regulation of cellular responses) activation, both in human astrocytes (but not in microglia) and in cuprizone-treated mice [155].

\section{Novel or Emerging MS Therapies and Neuroprotection}

Although existing first-line therapies in MS (i.e. IFN- $\beta$ and GA) seem to succeed in ameliorating the inflammation that heralds the demyelination process, there is an unmet need for therapies aiming at axonal degeneration that would hinder/hamper disability. It seems this is being partially addressed by some novel drugs that were recently added to our therapeutic armamentarium or are going to be approved in the near future. To this end, fingolimod, apart from its main immunomodulating role (i.e. the prevention of lymphocyte egress from lymph nodes) upregulates the in vitro microglial production of brain-derived neurotrophic factor (BDNF) and glialcell-derived neurotrophic factor, suggesting the promotion of the neuroprotective effects of microglia [156]. A putative neuroprotective role, apart from its anti-inflammatory properties, has also been ascribed to laquinimod, as it has been associated with increased serum levels of BDNF [157]. In addition, in the MOG-induced EAE model, laquinimod treatment, apart from reducing glutamatergic transmission while increasing GABAergic transmission, also preserved cannabinoid CB1 receptor sensitivity, which is normally lost during EAE induction, thus limiting glutamate excitoxicity and possibly axonal damage [158]. Dimethyl fumarate, a molecule previously used as fumaric acid esters in psoriasis therapy, has recently proved beneficial in MS. Although hypothesized to exert its immunologic effects by shifting cytokine production from a 'Th1' pattern to a 'Th2' pattern (the basis of its usage in dermatology) novel mechanisms of action have recently been proposed. In this respect, the applica- tion of dimethyl fumarate was associated with activation of the transcription factor nuclear (erythroid-derived 2)-related factor (Nrf2) and subsequently with the protection of glial cells against oxidative stress (possibly via glutathione recycling) [159]. Furthermore, it was recently suggested that activation of Nrf2 may be partially attributed to the modified astrocyte expression of histone deacetylases regulated by dimethyl fumarate [160]. Both the new monoclonal antibodies introduced in MS treatment seem to have a neuroprotective function. On the one hand, natalizumab reduced the CSF neurofilament level 3-fold, which is a biomarker of axonal damage [161]. On the other hand, lymphocytes reconstituting/ regenerating after alemtuzumab treatment produced increased concentrations of BDNF, platelet-derived growth factor and ciliary neurotrophic factor, which may contribute to the sustained improvement of disability, thereby supporting the notion of neuroprotective autoimmunity [162]. Based on the concept that impaired energy balance underlies axonal degeneration and the progression of disability (especially in primary/secondary progressive MS), which, in part, is caused by excess accumulation of intra-axonal $\mathrm{Na}^{+}$and $\mathrm{Ca}^{2+}$ ions, targeting voltage-gated sodium channels would exert a neuroprotective effect. In this regard, blocking acid-sensing ion channel 1 (ASIC1) with amiloride in patients with primary progressive MS results in a significant reduction in the rate of whole-brain atrophy. Immunohistochemical studies on postmortem spinal-cord tissue acquired from primary progressive MS patients have demonstrated the increased expression of ASIC1 in axons and oligodendrocytes in chronic inactive lesions [163]. Similar results in terms of protection against axonal degeneration in 2 EAE models were obtained with 2 additional sodium channel blockers, sefinamide and flecainide. Notably, both potently suppressed microglial activation via an independent mechanism [164]. Another trial with topiramate, a partial $\mathrm{Na}^{+}$channel blocker is underway. The potential of neuroprotection with sodium channel blockers seems especially pertinent with the provocative news that a high salt concentration promotes the differentiation of CD4+ T cells into Th17 cells in vitro and exacerbates the course of EAE in vivo [165]. Finally, another promising strategy that favors/serves both neuroprotection and remyelination is to antagonize LINGO-1 (leucine-rich repeat and immunoglobulin-domain-containing 1) a CNS-specific protein expressed on both neurons and oligodendrocytes. LINGO-1 forms a complex with the Nogo receptor and inhibits neurite outgrowth, but has recently been documented as a key negative regulator 
of the differentiation and myelination of oligodendrocyte progenitor cells [166]. A phase-I trial with antiLINGO-1 antibody BIIB033 is currently underway (ClinicalTrials.gov identifier: NCT01244139).

\section{Conclusions}

In spite of the major advancements in the mechanisms involved in the re-establishment of immune homeostasis in EAE, the developing protocols aimed at the specific suppression of the autoimmune response are still in their infancy and cell-based therapies hold the greatest promise for achieving these aims. As we learn more about the cells, molecules and pathways involved in the induction of tolerance during an autoimmune disease, we will progress toward developing novel therapeutic protocols that could result in the prevention or even reversal of unwanted immunity. The satisfaction derived from new findings on MS regulatory mechanisms will only be fully realized when such insights are translated into new therapeutic protocols.

\section{Acknowledgments}

This work was supported by grants from the Greek General Secretariat of Research and Technology (Synergasia 09SYN-121074 to P.V.).

\section{References}

$\checkmark 1$ Koch-Henriksen N, Sorensen PS: The changing demographic pattern of multiple sclerosis epidemiology. Lancet Neurol 2010;9:520532.

2 Hafler DA: Multiple sclerosis. J Clin Invest 2004;113:788-794.

3 Goverman J: Autoimmune T cell responses in the central nervous system. Nat Rev Immunol 2009;9:393-407.

4 Wekerle H: Lessons from multiple sclerosis: models, concepts, observations. Ann Rheum Dis 2008;67(suppl 3):iii56- iii60.

5 McFarland HF, Martin R: Multiple sclerosis: a complicated picture of autoimmunity. Nat Immunol 2007;8:913-919.

6 Stys PK, Zamponi GW, van Minnen J, Geurts $\mathrm{JJ}$ : Will the real multiple sclerosis please stand up? Nat Rev Neurosci 2012;13:507-514.

7 Goldenberg MM: Multiple sclerosis review. P T 2012;37:175-184.

8 Kurtzke JF: A reassessment of the distribution of multiple sclerosis. I. Acta Neurol Scand 1975;51:110-136.

9 Kurtzke JF: A reassessment of the distribution of multiple sclerosis. Acta Neurol Scand 1975; 51:137-157.

10 Pugliatti M, Rosati G, Carton H, Riise T, Drulovic J, Vecsei L, Milanov I: The epidemiology of multiple sclerosis in Europe. Eur J Neurol 2006;13:700-722.

-11 Kotzamani D, Panou T, Mastorodemos V, Tzagournissakis M, Nikolakaki H, Spanaki C, Plaitakis A: Rising incidence of multiple sclerosis in females associated with urbanization. Neurology 2012;78:1728-1735.

12 Simpson S Jr, Blizzard L, Otahal P, Van der Mei I, Taylor B: Latitude is significantly associated with the prevalence of multiple sclerosis: a meta-analysis. J Neurol Neurosurg Psychiatry 2011;82:1132-1141.

13 Zivadinov R, Iona L, Monti-Bragadin L, Bosco A, Jurjevic A, Taus C, Cazzato G, Zorzon $\mathrm{M}$ : The use of standardized incidence and prevalence rates in epidemiological studies on multiple sclerosis. A meta-analysis study. Neuroepidemiology 2003;22:65-74.

14 Alonso A, Hernan MA: Temporal trends in the incidence of multiple sclerosis: a systematic review. Neurology 2008;71:129-135.

15 Orton SM, Herrera BM, Yee IM, Valdar W, Ramagopalan SV, Sadovnick AD, Ebers GC: Sex ratio of multiple sclerosis in Canada: a longitudinal study. Lancet Neurol 2006;5: 932-936.

16 Bentzen J, Flachs EM, Stenager E, BronnumHansen H, Koch-Henriksen N: Prevalence of multiple sclerosis in Denmark 1950-2005. Mult Scler 2010;16:520-525.

17 Orton SM, Ramagopalan SV, Brocklebank D, Herrera BM, Dyment DA, Yee IM, Sadovnick $A D$, Ebers GC: Effect of immigration on multiple sclerosis sex ratio in Canada: the Canadian Collaborative Study. J Neurol Neurosurg Psychiatry 2010;81:31-36.

18 Dyment DA, Ebers GC, Sadovnick AD: Genetics of multiple sclerosis. Lancet Neurol 2004;3:104-110.

19 Ebers GC: Environmental factors and multiple sclerosis. Lancet Neurol 2008;7:268-277.

20 Jersild C, Svejgaard A, Fog T: HL-A antigens and multiple sclerosis. Lancet 1972;1:12401241.

-21 Ramagopalan SV, Dobson R, Meier UC, Giovannoni G: Multiple sclerosis: risk factors, prodromes, and potential causal pathways. Lancet Neurol 2010;9:727-739.

22 Chao MJ, Ramagopalan SV, Herrera BM, Orton SM, Handunnetthi L, Lincoln MR, Dyment DA, Sadovnick AD, Ebers GC: MHC transmission: insights into gender bias in MS susceptibility. Neurology 2011;76: 242-246.

-23 Hafler DA, Compston A, Sawcer S, Lander ES, Daly MJ, De Jager PL, de Bakker PI, Gabriel SB, Mirel DB, Ivinson AJ, Pericak-Vance MA, Gregory SG, Rioux JD, McCauley JL,
Haines JL, Barcellos LF, Cree B, Oksenberg JR, Hauser SL: Risk alleles for multiple sclerosis identified by a genome-wide study. $\mathrm{N}$ Engl J Med 2007;357:851-862.

24 Gourraud PA, Harbo HF, Hauser SL, Baranzini SE: The genetics of multiple sclerosis: an up-to-date review. Immunol Rev 2012;248: 87-103.

25 Ramagopalan SV, Dyment DA, Cader MZ, Morrison KM, Disanto G, Morahan JM, Berlanga-Taylor AJ, Handel A, De Luca GC, Sadovnick $\mathrm{AD}$, Lepage $\mathrm{P}$, Montpetit A, Ebers GC: Rare variants in the CYP27B1 gene are associated with multiple sclerosis. Ann Neurol 2011;70:881-886.

26 Wucherpfennig KW, Sette A, Southwood S, Oseroff C, Matsui M, Strominger JL, Hafler DA: Structural requirements for binding of an immunodominant myelin basic protein peptide to DR2 isotypes and for its recognition by human T cell clones. J Exp Med 1994;179: 279-290.

27 Martin R, Howell MD, Jaraquemada D, Flerlage $\mathrm{M}$, Richert J, Brostoff S, Long EO, McFarlin DE, McFarland HF: A myelin basic protein peptide is recognized by cytotoxic $\mathrm{T}$ cells in the context of four HLA-DR types associated with multiple sclerosis. J Exp Med 1991;173:19-24.

28 Ota K, Matsui M, Milford EL, Mackin GA, Weiner HL, Hafler DA: T-cell recognition of an immunodominant myelin basic protein epitope in multiple sclerosis. Nature 1990; 346:183-187.

29 Pette M, Fujita K, Wilkinson D, Altmann DM, Trowsdale J, Giegerich G, Hinkkanen A, Epplen JT, Kappos L, Wekerle H: Myelin autoreactivity in multiple sclerosis: recognition of myelin basic protein in the context of HLA-DR2 products by $\mathrm{T}$ lymphocytes of multiple-sclerosis patients and healthy donors. Proc Natl Acad Sci USA 1990;87:79687972. 
- 30 Zhang J, Markovic-Plese S, Lacet B, Raus J, Weiner HL, Hafler DA: Increased frequency of interleukin 2-responsive T cells specific for myelin basic protein and proteolipid protein in peripheral blood and cerebrospinal fluid of patients with multiple sclerosis. J Exp Med 1994;179:973-984.

- 31 Hafler DA, Duby AD, Lee SJ, Benjamin D, Seidman JG, Weiner HL: Oligoclonal T lymphocytes in the cerebrospinal fluid of patients with multiple sclerosis. J Exp Med 1988;167: 1313-1322.

32 Babbe H, Roers A, Waisman A, Lassmann H, Goebels N, Hohlfeld R, Friese M, Schroder R, Deckert M, Schmidt S, Ravid R, Rajewsky K Clonal expansions of CD8(+) T cells dominate the $\mathrm{T}$ cell infiltrate in active multiple sclerosis lesions as shown by micromanipulation and single cell polymerase chain reaction. J Exp Med 2000;192:393-404.

-33 Miller SD, Karpus WJ: Experimental autoimmune encephalomyelitis in the mouse. Curr Protoc Immunol 2007, doi: 10.1002/047 1142735.im1501s77.

- 34 Scheikl T, Pignolet B, Mars LT, Liblau RS: Transgenic mouse models of multiple sclerosis. Cell Mol Life Sci 2010;67:4011-4034.

- 35 Bailey SL, Schreiner B, McMahon EJ, Miller SD: CNS myeloid DCs presenting endogenous myelin peptides 'preferentially' polarize CD4+ Th-17 cells in relapsing EAE. Nat Immunol 2007;8:172-180.

-36 Hellings N, Raus J, Stinissen P: Insights into the immunopathogenesis of multiple sclerosis. Immunol Res 2002;25:27-51.

37 Olsson T: Cytokines in neuroinflammatory disease: role of myelin autoreactive $\mathrm{T}$ cell production of interferon-gamma. J Neuroimmunol 1992;40:211-218.

38 Ferber IA, Brocke S, Taylor-Edwards C, Ridgway W, Dinisco C, Steinman L, Dalton D, Fathman CG: Mice with a disrupted IFNgamma gene are susceptible to the induction of experimental autoimmune encephalomyelitis (EAE). J Immunol 1996;156:5-7.

-39 Cua DJ, Sherlock J, Chen Y, Murphy CA, Joyce B, Seymour B, Lucian L, To W, Kwan S, Churakova T, Zurawski S, Wiekowski M, Lira SA, Gorman D, Kastelein RA, Sedgwick JD: Interleukin-23 rather than interleukin-12 is the critical cytokine for autoimmune inflammation of the brain. Nature 2003;421:744-748.

-40 Langrish CL, Chen Y, Blumenschein WM, Mattson J, Basham B, Sedgwick JD, McClanahan T, Kastelein RA, Cua DJ: IL-23 drives a pathogenic $\mathrm{T}$ cell population that induces autoimmune inflammation. J Exp Med 2005;201:233-240.

-41 Durelli L, Conti L, Clerico M, Boselli D, Contessa G, Ripellino P, Ferrero B, Eid P, Novelli F: T-helper 17 cells expand in multiple sclerosis and are inhibited by interferon-beta. Ann Neurol 2009;65:499-509.

-42 Disanto G, Morahan JM, Barnett MH, Giovannoni G, Ramagopalan SV: The evidence for a role of B cells in multiple sclerosis. Neurology 2012;78:823-832.
43 Magliozzi R, Howell O, Vora A, Serafini B, Nicholas R, Puopolo M, Reynolds R, Aloisi F: Meningeal B-cell follicles in secondary progressive multiple sclerosis associate with early onset of disease and severe cortical pathology. Brain 2007;130:1089-1104.

-44 McLaughlin KA, Wucherpfennig KW: B cells and autoantibodies in the pathogenesis of multiple sclerosis and related inflammatory demyelinating diseases. Adv Immunol 2008; 98:121-149.

45 Krishnamoorthy G, Lassmann H, Wekerle H, Holz A: Spontaneous opticospinal encephalomyelitis in a double-transgenic mouse model of autoimmune $\mathrm{T}$ cell/B cell cooperation. J Clin Invest 2006;116:2385-2392.

46 Apostolou I, Verginis P, Kretschmer K, Polansky J, Huhn J, von Boehmer H: Peripherally induced Treg: mode, stability, and role in specific tolerance. J Clin Immunol 2008;28:619-624.

47 Sakaguchi S: Regulatory T cells: key controllers of immunologic self-tolerance. Cell 2000; 101:455-458.

48 Sakaguchi S, Sakaguchi N, Asano M, Itoh M, Toda M: Immunologic self-tolerance maintained by activated T cells expressing IL- 2 receptor alpha-chains (CD25). Breakdown of a single mechanism of self-tolerance causes various autoimmune diseases. J Immunol 1995; 155:1151-1164.

49 Sakaguchi S, Ono M, Setoguchi R, Yagi H, Hori S, Fehervari Z, Shimizu J, Takahashi T, Nomura T: Foxp3+ CD25+ CD4+ natural regulatory $\mathrm{T}$ cells in dominant self-tolerance and autoimmune disease. Immunol Rev 2006; 212:8-27.

50 Bluestone JA, Abbas AK: Natural versus adaptive regulatory $\mathrm{T}$ cells. Nat Rev Immunol 2003;3:253-257.

51 Khattri R, Cox T, Yasayko SA, Ramsdell F: An essential role for Scurfin in CD4+CD25+ T regulatory cells. Nat Immunol 2003;4:337-342.

52 Fontenot JD, Gavin MA, Rudensky AY: Foxp3 programs the development and function of CD4+CD25+ regulatory T cells. Nat Immunol 2003;4:330-336.

53 Hori S, Nomura T, Sakaguchi S: Control of regulatory $\mathrm{T}$ cell development by the transcription factor Foxp3. Science 2003;299:1057-1061.

54 Ziegler SF: FOXP3:of mice and men. Annu Rev Immunol 2006;24:209-226.

55 Viglietta V, Baecher-Allan C, Weiner HL, Hafler DA: Loss of functional suppression by CD4+CD25+ regulatory $\mathrm{T}$ cells in patients with multiple sclerosis. J Exp Med 2004;199: 971-979.

56 Tsaknaridis L, Spencer L, Culbertson N, Hicks K, LaTocha D, Chou YK, Whitham RH, Bakke A, Jones RE, Offner H, Bourdette DN, Vandenbark AA: Functional assay for human CD4+CD25+ Treg cells reveals an age-dependent loss of suppressive activity. J Neurosci Res 2003;74:296-308.

57 Frisullo G, Nociti V, Iorio R, Patanella AK, Caggiula M, Marti A, Sancricca C, Angelucci F, Mirabella M, Tonali PA, Batocchi AP: Regulatory $\mathrm{T}$ cells fail to suppress $\mathrm{CD} 4 \mathrm{~T}+$-bet+ $\mathrm{T}$ cells in relapsing multiple sclerosis patients. Immunology 2009;127:418-428.

58 Feger U, Luther C, Poeschel S, Melms A, Tolosa $\mathrm{E}$, Wiendl $\mathrm{H}$ : Increased frequency of CD4+ CD25+ regulatory T cells in the cerebrospinal fluid but not in the blood of multiple sclerosis patients. Clin Exp Immunol 2007;147:412-418.

59 Haas J, Hug A, Viehover A, Fritzsching B, Falk CS, Filser A, Vetter T, Milkova L, Korporal M, Fritz B, Storch-Hagenlocher B, Krammer PH, Suri-Payer E, Wildemann B: Reduced suppressive effect of CD4+CD25 high regulatory $\mathrm{T}$ cells on the $\mathrm{T}$ cell immune response against myelin oligodendrocyte glycoprotein in patients with multiple sclerosis. Eur J Immunol 2005;35:3343-3352.

60 de Andres C, Aristimuno C, de Las Heras V, Martinez-Gines ML, Bartolome M, Arroyo R, Navarro J, Gimenez-Roldan S, FernandezCruz E, Sanchez-Ramon S: Interferon beta-1a therapy enhances $\mathrm{CD} 4+$ regulatory $\mathrm{T}$-cell function: an ex vivo and in vitro longitudinal study in relapsing-remitting multiple sclerosis. J Neuroimmunol 2007;182:204-211.

61 Korporal M, Haas J, Balint B, Fritzsching B, Schwarz A, Moeller S, Fritz B, Suri-Payer E, Wildemann B: Interferon beta-induced restoration of regulatory $\mathrm{T}$-cell function in multiple sclerosis is prompted by an increase in newly generated naive regulatory $\mathrm{T}$ cells. Arch Neurol 2008;65:1434-1439.

62 Hong J, Li N, Zhang X, Zheng B, Zhang JZ: Induction of $\mathrm{CD} 4+\mathrm{CD} 25+$ regulatory $\mathrm{T}$ cells by copolymer-I through activation of transcription factor Foxp3. Proc Natl Acad Sci USA 2005;102:6449-6454.

$63 \mathrm{Xu} \mathrm{L}, \mathrm{Xu} Z$ Z, Xu M: Glucocorticoid treatment restores the impaired suppressive function of regulatory $\mathrm{T}$ cells in patients with relapsingremitting multiple sclerosis. Clin Exp Immunol 2009; 158:26-30.

64 Huan J, Culbertson N, Spencer L, Bartholomew R, Burrows GG, Chou YK, Bourdette D, Ziegler SF, Offner H, Vandenbark AA: Decreased FOXP3 levels in multiple sclerosis patients. J Neurosci Res 2005;81:45-52.

65 Stenner MP, Waschbisch A, Buck D, Doerck S, Einsele H, Toyka KV, Wiendl H: Effects of natalizumab treatment on Foxp3+ T regulatory cells. PLoS One 2008;3:e3319.

66 Havari E, Turner MJ, Campos-Rivera J, Shankara S, Nguyen TH, Roberts B, Siders W, Kaplan JM: Impact of alemtuzumab treatment on the survival and function of human regulatory $\mathrm{T}$ cells in vitro. Immunology 2014;141:123-131.

67 Lafaille JJ, Nagashima K, Katsuki M, Tonegawa S: High incidence of spontaneous autoimmune encephalomyelitis in immunodeficient anti-myelin basic protein $\mathrm{T}$ cell receptor transgenic mice. Cell 1994;78:399-408.

68 Olivares-Villagomez D, Wang Y, Lafaille JJ Regulatory CD4(+) T cells expressing endogenous $\mathrm{T}$ cell receptor chains protect myelin basic protein-specific transgenic mice from spontaneous autoimmune encephalomyelitis. J Exp Med 1998;188:1883-1894. 
-69 Kohm AP, Carpentier PA, Anger HA, Miller SD: Cutting edge: $\mathrm{CD} 4+\mathrm{CD} 25+$ regulatory $\mathrm{T}$ cells suppress antigen-specific autoreactive immune responses and central nervous system inflammation during active experimental autoimmune encephalomyelitis. J Immunol 2002;169:4712-4716.

-70 Zhang X, Koldzic DN, Izikson L, Reddy J, Nazareno RF, Sakaguchi S, Kuchroo VK, Weiner HL: IL-10 is involved in the suppression of experimental autoimmune encephalomyelitis by $\mathrm{CD} 25+\mathrm{CD} 4+$ regulatory $\mathrm{T}$ cells. Int Immunol 2004;16:249-256.

-71 Stephens LA, Gray D, Anderton SM: CD4+ $\mathrm{CD} 25+$ regulatory $\mathrm{T}$ cells limit the risk of autoimmune disease arising from $\mathrm{T}$ cell receptor cross-reactivity. Proc Natl Acad Sci USA 2005;102:17418-17423.

72 Reddy J, Illes Z, Zhang X, Encinas J, Pyrdol J, Nicholson L, Sobel RA, Wucherpfennig KW, Kuchroo VK: Myelin proteolipid proteinspecific CD4+CD25+ regulatory cells mediate genetic resistance to experimental autoimmune encephalomyelitis. Proc Natl Acad Sci USA 2004;101:15434-15439.

-73 Korn T, Reddy J, Gao W, Bettelli E, Awasthi A, Petersen TR, Backstrom BT, Sobel RA, Wucherpfennig KW, Strom TB, Oukka M, Kuchroo VK: Myelin-specific regulatory $\mathrm{T}$ cells accumulate in the CNS but fail to control autoimmune inflammation. Nat Med 2007; 13:423-431.

74 Liu Y, Zhang P, Li J, Kulkarni AB, Perruche S, Chen W: A critical function for TGF-beta signaling in the development of natural CD4+ CD25+Foxp3+ regulatory T cells. Nat Immunol 2008;9:632-640.

75 Verginis P, Li HS, Carayanniotis G: Tolerogenic semimature dendritic cells suppress experimental autoimmune thyroiditis by activation of thyroglobulin-specific CD4+ CD25+ T cells. J Immunol 2005;174:74337439.

76 Pulendran B, Tang H, Manicassamy S: Programming dendritic cells to induce Th2 and tolerogenic responses. Nat Immunol 2010;11: 647-655.

-77 Kavousanaki M, Makrigiannakis A, Boumpas D, Verginis P: Novel role of plasmacytoid dendritic cells in humans: induction of interleukin-10-producing Treg cells by plasmacytoid dendritic cells in patients with rheumatoid arthritis responding to therapy. Arthritis Rheum 2010;62:53-63.

-78 Menges M, Rossner S, Voigtlander C, Schindler H, Kukutsch NA, Bogdan C, Erb K, Schuler G, Lutz MB: Repetitive injections of dendritic cells matured with tumor necrosis factor alpha induce antigen-specific protection of mice from autoimmunity. J Exp Med 2002;195:15-21.

79 Hirata S, Senju S, Matsuyoshi H, Fukuma D, Uemura Y, Nishimura Y: Prevention of experimental autoimmune encephalomyelitis by transfer of embryonic stem cell-derived dendritic cells expressing myelin oligodendrocyte glycoprotein peptide along with
TRAIL or programmed death-1 ligand. J Immunol 2005;174:1888-1897.

80 Irla M, Kupfer N, Suter T, Lissilaa R, Benkhoucha M, Skupsky J, Lalive PH, Fontana A, Reith W, Hugues S: MHC class II-restricted antigen presentation by plasmacytoid dendritic cells inhibits T cell-mediated autoimmunity. J Exp Med 2010;207:1891-1905.

81 Bailey-Bucktrout SL, Caulkins SC, Goings G, Fischer JA, Dzionek A, Miller SD: Cutting edge: central nervous system plasmacytoid dendritic cells regulate the severity of relapsing experimental autoimmune encephalomyelitis. J Immunol 2008;180:6457-6461.

82 Isaksson M, Ardesjo B, Ronnblom L, Kampe O, Lassmann H, Eloranta ML, Lobell A: Plasmacytoid DC promote priming of autoimmune Th17 cells and EAE. Eur J Immunol 2009;39:2925-2935.

83 Yong VW: Differential mechanisms of action of interferon-beta and glatiramer acetate in MS. Neurology 2002;59:802-808.

84 Balashov KE, Aung LL, Vaknin-Dembinsky A, Dhib-Jalbut S, Weiner HL: Interferon-beta inhibits Toll-like receptor 9 processing in multiple sclerosis. Ann Neurol 2010;68:899-906.

85 Sweeney CM, Lonergan R, Basdeo SA, Kinsella K, Dungan LS, Higgins SC, Kelly PJ, Costelloe L, Tubridy N, Mills KH, Fletcher JM: IL-27 mediates the response to IFN-beta therapy in multiple sclerosis patients by inhibiting Th17 cells. Brain Behav Immun 2011; 25:1170-1181.

86 del Pilar Martin M, Cravens PD, Winger R, Frohman EM, Racke MK, Eagar TN, Zamvil SS, Weber MS, Hemmer B, Karandikar NJ, Kleinschmidt-DeMasters BK, Stuve O: Decrease in the numbers of dendritic cells and CD4+ T cells in cerebral perivascular spaces due to natalizumab. Arch Neurol 2008; 65: 1596-1603.

87 Vieira PL, Heystek HC, Wormmeester J, Wierenga EA, Kapsenberg ML: Glatiramer acetate (copolymer-1, copaxone) promotes Th2 cell development and increased IL-10 production through modulation of dendritic cells. J Immunol 2003;170:4483-4488.

88 Kim HJ, Ifergan I, Antel JP, Seguin R, Duddy M, Lapierre Y, Jalili F, Bar-Or A: Type 2 monocyte and microglia differentiation mediated by glatiramer acetate therapy in patients with multiple sclerosis. J Immunol 2004;172:7144-7153.

89 Weber MS, Prod'homme T, Youssef S, Dunn SE, Rundle CD, Lee L, Patarroyo JC, Stuve O, Sobel RA, Steinman L, Zamvil SS: Type II monocytes modulate $\mathrm{T}$ cell-mediated central nervous system autoimmune disease. Nat Med 2007;13:935-943.

90 Comabella M, Lunemann JD, Rio J, Sanchez A, Lopez C, Julia E, Fernandez M, Nonell L, Camina-Tato M, Deisenhammer F, Caballero E, Tortola MT, Prinz M, Montalban X, Martin $\mathrm{R}$ : A type I interferon signature in monocytes is associated with poor response to interferon-beta in multiple sclerosis. Brain 2009;132: 3353-3365.
91 Kowarik MC, Pellkofer HL, Cepok S, Korn T, Kumpfel T, Buck D, Hohlfeld R, Berthele A, Hemmer B: Differential effects of fingolimod (FTY720) on immune cells in the CSF and blood of patients with MS. Neurology 2011;76:1214-1221.

92 Freedman MS, Kaplan JM, Markovic-Plese $S$ : Insights into the mechanisms of the therapeutic efficacy of alemtuzumab in multiple sclerosis. J Clin Cell Immunol 2013;4;1-18.

93 Murray PJ, Wynn TA: Protective and pathogenic functions of macrophage subsets. Nat Rev Immunol 2011;11:723-737.

94 Huang DR, Wang J, Kivisakk P, Rollins BJ, Ransohoff RM: Absence of monocyte chemoattractant protein 1 in mice leads to decreased local macrophage recruitment and antigen-specific T helper cell type 1 immune response in experimental autoimmune encephalomyelitis. J Exp Med 2001;193:713726.

-95 Hendriks JJ, Teunissen CE, de Vries HE, Dijkstra CD: Macrophages and neurodegeneration. Brain Res Brain Res Rev 2005;48: 185-195.

-96 Kiefer R, Kieseier BC, Stoll G, Hartung HP: The role of macrophages in immune-mediated damage to the peripheral nervous system. Prog Neurobiol 2001;64:109-127.

97 Gabrilovich DI, Nagaraj S: Myeloid-derived suppressor cells as regulators of the immune system. Nat Rev Immunol 2009;9: 162-174.

98 Nagaraj S, Collazo M, Corzo CA, Youn JI, Ortiz M, Quiceno D, Gabrilovich DI: Regulatory myeloid suppressor cells in health and disease. Cancer Res 2009;69:7503-7506.

-99 Rabinovich GA, Gabrilovich D, Sotomayor EM: Immunosuppressive strategies that are mediated by tumor cells. Annu Rev Immunol 2007;25:267-296.

100 Delano MJ, Scumpia PO, Weinstein JS, Coco D, Nagaraj S, Kelly-Scumpia KM, O’Malley KA, Wynn JL, Antonenko S, Al-Quran SZ, Swan R, Chung CS, Atkinson MA, Ramphal R, Gabrilovich DI, Reeves WH, Ayala A, Phillips J, Laface D, Heyworth PG, ClareSalzler M, Moldawer LL: MyD88-dependent expansion of an immature GR-1(+) $\mathrm{CD} 11 \mathrm{~b}(+)$ population induces $\mathrm{T}$ cell suppression and Th2 polarization in sepsis. J Exp Med 2007;204:1463-1474.

101 Serafini P, Borrello I, Bronte V: Myeloid suppressor cells in cancer: recruitment, phenotype, properties, and mechanisms of immune suppression. Semin Cancer Biol 2006; 16:53-65.

102 Garcia MR, Ledgerwood L, Yang Y, Xu J, Lal G, Burrell B, Ma G, Hashimoto D, Li Y, Boros P, Grisotto M, van Rooijen N, Matesanz R, Tacke F, Ginhoux F, Ding Y, Chen SH, Randolph G, Merad M, Bromberg JS, Ochando JC: Monocytic suppressive cells mediate cardiovascular transplantation tolerance in mice. J Clin Invest 2010;120: 2486-2496 
-103 Marigo I, Bosio E, Solito S, Mesa C, Fernandez A, Dolcetti L, Ugel S, Sonda N, Bicciato S, Falisi E, Calabrese F, Basso G, Zanovello P, Cozzi E, Mandruzzato S, Bronte V: Tumorinduced tolerance and immune suppression depend on the C/EBPbeta transcription factor. Immunity 2010;32:790-802.

104 Boros P, Ochando JC, Chen SH, Bromberg JS: Myeloid-derived suppressor cells: natural regulators for transplant tolerance. Hum Immunol 2010;71:1061-1066.

105 Gabrilovich DI, Bronte V, Chen SH, Colombo MP, Ochoa A, Ostrand-Rosenberg S, Schreiber H: The terminology issue for myeloid-derived suppressor cells. Cancer Res 2007;67:425.

106 Ribechini E, Greifenberg V, Sandwick S, Lutz MB: Subsets, expansion and activation of myeloid-derived suppressor cells. Med Microbiol Immunol 2010;199:273-281.

-107 Youn JI, Nagaraj S, Collazo M, Gabrilovich DI: Subsets of myeloid-derived suppressor cells in tumor-bearing mice. J Immunol 2008;181:5791-5802.

-108 Ioannou M, Alissafi T, Lazaridis I, Deraos G, Matsoukas J, Gravanis A, Mastorodemos V, Plaitakis A, Sharpe A, Boumpas D, Verginis P: Crucial role of granulocytic myeloid-derived suppressor cells in the regulation of central nervous system autoimmune disease. J Immunol 2012;188:1136-1146.

109 Dardalhon V, Anderson AC, Karman J, Apetoh L, Chandwaskar R, Lee DH, Cornejo M, Nishi N, Yamauchi A, Quintana FJ, Sobel RA, Hirashima M, Kuchroo VK: Tim-3/galectin-9 pathway: regulation of Th1 immunity through promotion of CD11b+Ly-6G+ myeloid cells. J Immunol 2010;185:1383-1392.

$\checkmark 110$ Zhu B, Bando Y, Xiao S, Yang K, Anderson AC, Kuchroo VK, Khoury SJ: CD11b+Ly$6 \mathrm{C}$ (hi) suppressive monocytes in experimental autoimmune encephalomyelitis. I Immunol 2007;179:5228-5237.

111 King IL, Dickendesher TL, Segal BM: Circulating Ly-6C+ myeloid precursors migrate to the CNS and play a pathogenic role during autoimmune demyelinating disease. Blood 2009;113:3190-3197.

112 Mildner A, Mack M, Schmidt H, Bruck W, Djukic M, Zabel MD, Hille A, Priller J, Prinz M: CCR2+Ly-6Chi monocytes are crucial for the effector phase of autoimmunity in the central nervous system. Brain 2009;132: 2487-2500.

-113 Stinissen P, Zhang J, Vandevyver C, Hermans G, Raus J: Gammadelta T cell responses to activated $\mathrm{T}$ cells in multiple sclerosis patients induced by $\mathrm{T}$ cell vaccination. $\mathrm{J}$ Neuroimmunol 1998;87:94-104.

-114 Elliott CL, El-Touny SY, Filipi ML, Healey KM, Leuschen MP: Interferon betala treatment modulates TH1 expression in gammadelta $+\mathrm{T}$ cells from relapsing-remitting multiple sclerosis patients. J Clin Immunol 2001;21:200-209.

115 Kobayashi Y, Kawai K, Ito K, Honda H, Sobue G, Yoshikai Y: Aggravation of murine experimental allergic encephalomyelitis by administration of T-cell receptor gammadelta-specific antibody. J Neuroimmunol 1997;73:169-174.

116 Ponomarev ED, Dittel BN: Gamma delta T cells regulate the extent and duration of inflammation in the central nervous system by a Fas ligand-dependent mechanism. J Immunol 2005;174:4678-4687.

-117 Matsushita T, Yanaba K, Bouaziz JD, Fujimoto M, Tedder TF: Regulatory B cells inhibit EAE initiation in mice while other B cells promote disease progression. J Clin Invest $2008 ; 118: 3420-3430$.

118 Mann MK, Maresz K, Shriver LP, Tan Y, Dittel BN: B cell regulation of CD4+CD25+ T regulatory cells and IL-10 via B7 is essential for recovery from experimental autoimmune encephalomyelitis. J Immunol 2007; 178:3447-3456.

-119 Kawano T, Cui J, Koezuka Y, Toura I, Kaneko Y, Motoki K, Ueno H, Nakagawa R, Sato H, Kondo E, Koseki H, Taniguchi M: CD1d-restricted and TCR-mediated activation of valpha14 NKT cells by glycosylceramides. Science 1997;278:1626-1629.

120 Bendelac A, Savage PB, Teyton L: The biology of NKT cells. Annu Rev Immunol 2007; 25:297-336.

121 Kronenberg M: Toward an understanding of NKT cell biology: progress and paradoxes. Annu Rev Immunol 2005;23:877-900.

122 Taniguchi M, Harada M, Kojo S, Nakayama T, Wakao $\mathrm{H}$ : The regulatory role of Valpha14 NKT cells in innate and acquired immune response. Annu Rev Immunol 2003; 21:483-513.

123 Abruzzo LV, Rowley DA: Homeostasis of the antibody response: immunoregulation by NK cells. Science 1983;222:581-585.

124 Takeda K, Dennert G: The development of autoimmunity in C57BL/6 lpr mice correlates with the disappearance of natural killer type 1-positive cells: evidence for their suppressive action on bone marrow stem cell proliferation, B cell immunoglobulin secretion, and autoimmune symptoms. J Exp Med 1993;177:155-164.

-125 Hammond KJ, Poulton LD, Palmisano LJ, Silveira PA, Godfrey DI, Baxter AG: alpha/beta$\mathrm{T}$ cell receptor (TCR)+CD4-CD8- (NKT) thymocytes prevent insulin-dependent diabetes mellitus in nonobese diabetic (NOD)/Lt mice by the influence of interleukin (IL)-4 and/or IL-10. JExp Med 1998; 187:1047-1056.

126 Sharif S, Arreaza GA, Zucker P, Mi QS, Sondhi J, Naidenko OV, Kronenberg M, Koezuka Y, Delovitch TL, Gombert JM, Leite-DeMoraes M, Gouarin C, Zhu R, Hameg A, Nakayama T, Taniguchi M, Lepault F, Lehuen A, Bach JF, Herbelin A: Activation of natural killer $\mathrm{T}$ cells by alpha-galactosylceramide treatment prevents the onset and recurrence of autoimmune type 1 diabetes. Nat Med 2001;7:1057-1062.

127 Sonoda KH, Faunce DE, Taniguchi M, Exley M, Balk S, Stein-Streilein J: NK T cell-de- rived IL-10 is essential for the differentiation of antigen-specific $\mathrm{T}$ regulatory cells in systemic tolerance. J Immunol 2001;166:42-50.

128 Merrill J, Jondal M, Seeley J, Ullberg M, Siden A: Decreased NK killing in patients with multiple sclerosis: an analysis on the level of the single effector cell in peripheral blood and cerebrospinal fluid in relation to the activity in the disease. Clin Exp Immunol 1982;47:419-430.

129 Munschauer FE, Hartrich LA, Stewart CC, Jacobs L: Circulating natural killer cells but not cytotoxic T lymphocytes are reduced in patients with active relapsing multiple sclerosis and little clinical disability as compared to controls. J Neuroimmunol 1995;62:177-181.

130 Vranes Z, Poljakovic Z, Marusic M: Natural killer cell number and activity in multiple sclerosis. J Neurol Sci 1989;94:115-123.

131 Takahashi K, Aranami T, Endoh M, Miyake S, Yamamura T: The regulatory role of natural killer cells in multiple sclerosis. Brain 2004;127:1917-1927.

132 Takahashi K, Miyake S, Kondo T, Terao K, Hatakenaka M, Hashimoto S, Yamamura T: Natural killer type 2 bias in remission of multiple sclerosis. J Clin Invest 2001;107:R23-R29.

133 Loza MJ, Zamai L, Azzoni L, Rosati E, Perussia B: Expression of type 1 (interferon gamma) and type 2 (interleukin-13, interleukin-5) cytokines at distinct stages of natural killer cell differentiation from progenitor cells. Blood 2002;99:1273-1281.

134 Matsumoto Y, Kohyama K, Aikawa Y, Shin T, Kawazoe Y, Suzuki Y, Tanuma N: Role of natural killer cells and TCR gamma delta T cells in acute autoimmune encephalomyelitis. Eur J Immunol 1998;28:1681-1688.

135 Zhang B, Yamamura T, Kondo T, Fujiwara M, Tabira T: Regulation of experimental autoimmune encephalomyelitis by natural killer (NK) cells. J Exp Med 1997;186:1677-1687.

136 Diab A, Michael L, Wahren B, Deng GM, Bjork J, Hedlund G, Zhu J: Linomide suppresses acute experimental autoimmune encephalomyelitis in Lewis rats by counteracting the imbalance of pro-inflammatory versus anti-inflammatory cytokines. J Neuroimmunol 1998;85:146-154.

137 Karussis DM, Lehmann D, Slavin S, VourkaKarussis U, Mizrachi-Koll R, Ovadia $\mathrm{H}$ Ben-Nun A, Kalland T, Abramsky O: Inhibition of acute, experimental autoimmune encephalomyelitis by the synthetic immunomodulator linomide. Ann Neurol 1993;34: 654-660.

138 Eralinna JP, Roytta M, Hukkanen V, Zinhu D, Salmi AA, Salonen R: Selective downregulation of Th1 response by Linomide reduces autoimmunity but increases susceptibility to viral infection in BALB/c and SJL mice. J Neuroimmunol 1998;88:165-176.

139 Zhu J, Diab A, Mustafa M, Levi M, Wahren B, Bjork J, Hedlund G: Linomide suppresses chronic-relapsing experimental autoimmune encephalomyelitis in DA rats. J Neurol Sci 1998;160:113-120. 
140 Smeltz RB, Wolf NA, Swanborg RH: Inhibition of autoimmune $\mathrm{T}$ cell responses in the DA rat by bone marrow-derived NK cells in vitro: implications for autoimmunity. J Immunol 1999;163:1390-1397.

141 Lee KM, Bhawan S, Majima T, Wei H, Nishimura MI, Yagita H, Kumar V: Cutting edge: the NK cell receptor 2B4 augments antigen-specific $\mathrm{T}$ cell cytotoxicity through CD48 ligation on neighboring T cells. J Immunol 2003;170:4881-4885.

142 Mailliard RB, Son YI, Redlinger R, Coates PT, Giermasz A, Morel PA, Storkus WJ, Kalinski P: Dendritic cells mediate NK cell help for Th1 and CTL responses: two-signal requirement for the induction of NK cell helper function. J Immunol 2003;171:23662373.

143 Illes Z, Kondo T, Newcombe J, Oka N, Tabira T, Yamamura T: Differential expression of NK T cell V alpha 24J alpha Q invariant TCR chain in the lesions of multiple sclerosis and chronic inflammatory demyelinating polyneuropathy. J Immunol 2000; 164:43754381.

144 Araki M, Kondo T, Gumperz JE, Brenner MB, Miyake S, Yamamura T: Th2 bias of CD4+ NKT cells derived from multiple sclerosis in remission. Int Immunol 2003;15: 279-288.

145 Gigli G, Caielli S, Cutuli D, Falcone M: Innate immunity modulates autoimmunity: type 1 interferon-beta treatment in multiple sclerosis promotes growth and function of regulatory invariant natural killer $\mathrm{T}$ cells through dendritic cell maturation. Immunology 2007;122:409-417.

146 Miyamoto K, Miyake S, Yamamura T: A synthetic glycolipid prevents autoimmune encephalomyelitis by inducing Th2 bias of natural killer T cells. Nature 2001;413:531534.

147 Jahng AW, Maricic I, Pedersen B, Burdin N, Naidenko O, Kronenberg M, Koezuka Y, Kumar V: Activation of natural killer T cells potentiates or prevents experimental autoimmune encephalomyelitis. J Exp Med 2001; 194:1789-1799.

148 Singh AK, Wilson MT, Hong S, OlivaresVillagomez D, Du C, Stanic AK, Joyce S, Sriram S, Koezuka Y, Van Kaer L: Natural killer $\mathrm{T}$ cell activation protects mice against experimental autoimmune encephalomyelitis. J Exp Med 2001;194:1801-1811.
149 Fritz RB, Zhao ML: Regulation of experimental autoimmune encephalomyelitis in the C57BL/6J mouse by NK1.1+, DX5+, alpha beta+ $T$ cells. J Immunol 2001;166: 4209-4215.

150 Frohman EM, Racke MK, Raine CS: Multiple sclerosis - the plaque and its pathogenesis. N Engl J Med 2006;354:942-955.

151 Brosnan CF, Raine CS: The astrocyte in multiple sclerosis revisited. Glia 2013;61:453465.

152 Cambron M, D’Haeseleer M, Laureys G, Clinckers R, Debruyne J, De Keyser J: Whitematter astrocytes, axonal energy metabolism, and axonal degeneration in multiple sclerosis. J Cereb Blood Flow Metab 2012;32: 413-424.

153 Lucchinetti CF, Guo Y, Popescu BF, Fujihara K, Itoyama Y, Misu T: The pathology of an autoimmune astrocytopathy: lessons learned from neuromyelitis optica. Brain Pathol 2014; 24:83-97.

154 Choi JW, Gardell SE, Herr DR, Rivera R, Lee CW, Noguchi K, Teo ST, Yung YC, Lu M, Kennedy G, Chun J: FTY720 (fingolimod) efficacy in an animal model of multiple sclerosis requires astrocyte sphingosine 1-phosphate receptor 1 (S1P1) modulation. Proc Natl Acad Sci USA 2011;108:751-756.

155 Bruck W, Pfortner R, Pham T, Zhang J, Hayardeny L, Piryatinsky V, Hanisch UK, Regen T, van Rossum D, Brakelmann L, Hagemeier K, Kuhlmann T, Stadelmann C, John GR, Kramann N, Wegner C: Reduced astrocytic NF-kappaB activation by laquinimod protects from cuprizone-induced demyelination. Acta Neuropathol 2012;124:411-424.

156 Noda H, Takeuchi H, Mizuno T, Suzumura A: Fingolimod phosphate promotes the neuroprotective effects of microglia. J Neuroimmunol 2013;256:13-18.

157 Bruck W, Wegner C: Insight into the mechanism of laquinimod action. J Neurol Sci 2011;306:173-179.

158 Ruffini F, Rossi S, Bergamaschi A, Brambilla E, Finardi A, Motta C, Studer V, Barbieri F, De Chiara V, Hayardeny L, Comi G, Centonze D, Martino G: Laquinimod prevents inflammation-induced synaptic alterations occurring in experimental autoimmune encephalomyelitis. Mult Scler 2013;19:10841094.
59 Linker RA, Lee DH, Ryan S, van Dam AM, Conrad R, Bista P, Zeng W, Hronowsky X, Buko A, Chollate S, Ellrichmann G, Bruck W, Dawson K, Goelz S, Wiese S, Scannevin RH, Lukashev M, Gold R: Fumaric acid esters exert neuroprotective effects in neuroinflammation via activation of the Nrf2 antioxidant pathway. Brain 2011;134:678692.

160 Kalinin S, Polak PE, Lin SX, Braun D, Guizzetti M, Zhang X, Rubinstein I, Feinstein DL: Dimethyl fumarate regulates histone deacetylase expression in astrocytes. J Neuroimmunol 2013;263:13-19.

161 Gunnarsson M, Malmestrom C, Axelsson M, Sundstrom P, Dahle C, Vrethem M, Olsson T, Piehl F, Norgren N, Rosengren L, Svenningsson A, Lycke J: Axonal damage in relapsing multiple sclerosis is markedly reduced by natalizumab. Ann Neurol 2011;69: 83-89.

162 Jones JL, Anderson JM, Phuah CL, Fox EJ, Selmaj K, Margolin D, Lake SL, Palmer J, Thompson SJ, Wilkins A, Webber DJ, Compston DA, Coles AJ: Improvement in disability after alemtuzumab treatment of multiple sclerosis is associated with neuroprotective autoimmunity. Brain 2010;133: 2232-2247.

163 Arun T, Tomassini V, Sbardella E, de Ruiter MB, Matthews L, Leite MI, Gelineau-Morel R, Cavey A, Vergo S, Craner M, Fugger L, Rovira A, Jenkinson M, Palace J: Targeting ASIC1 in primary progressive multiple sclerosis: evidence of neuroprotection with amiloride. Brain 2013;136:106-115.

164 Morsali D, Bechtold D, Lee W, Chauhdry S, Palchaudhuri U, Hassoon P, Snell DM, Malpass K, Piers T, Pocock J, Roach A, Smith KJ: Safinamide and flecainide protect axons and reduce microglial activation in models of multiple sclerosis. Brain 2013;136:10671082.

165 O'Shea JJ, Jones RG: Autoimmunity: rubbing salt in the wound. Nature 2013;496: 437-439.

166 Jepson S, Vought B, Gross CH, Gan L, Austen D, Frantz JD, Zwahlen J, Lowe D, Markland W, Krauss R: LINGO-1, a transmembrane signaling protein, inhibits oligodendrocyte differentiation and myelination through intercellular self-interactions. J Biol Chem 2012;287:22184-22195. 